K A N D A I

\begin{tabular}{|l|l|l|}
\hline Volume 15 & No. 1, Mei 2019 & Halaman 87-100 \\
\hline
\end{tabular}

\title{
LE PETIT PRINCE KARYA ANTOINE DE SAINT-EXUPERY \\ DALAM TANGGAPAN DAN HORIZON HARAPAN PEMBACA (Le Petit Prince of Antoine de Saint-Exupéry in Reader's Response and Horizon Hope)
}

\author{
Tania Intan \\ Universitas Padjadjaran \\ Jalan Raya Ir. Soekarno Km. 21,7 Jatinangor, Sumedang, Indonesia \\ Pos-el: tania.intan@unpad.ac.id
}

(Diterima: 7 Juli 2018 ; Direvisi: 7 Mei 2019; Disetujui: 8 Mei 2019)

\begin{abstract}
This study aims to describe the reader's responses to the novel Le Petit Prince, the readers' horizon of hope for the novel Le Petit Prince, and the factors that cause differences in responses and readers' expectation horizons. This study included a type of qualitative descriptive study. There are two data sources, namely primary and secondary data sources. The primary data source refers to the object of the research, the Le Petit Prince novel, while the secondary data is in the form of texts that contain the readers' responses of Le Petit Prince's novels consisting of 20 people, which are contained in print and electronic mass media including the internet. The research instrument is in the form of tables that link readers, readers' responses, and expectation horizons. Data is collected by means of observations and data analyzed using qualitative descriptive techniques. The results of the research are as follows. First, all readers respond or positively assess the elements of the theme, plot, character, setting, point of view, language style, storytelling techniques, language, and contents of the Le Petit Prince novel. Second, the hope of most readers before reading the Le Petit Prince novel is in accordance with the reality of the nine elements in the novel Le Petit Prince so that readers can easily receive and give praise to the novel. Third, the factors that cause differences in responses and readers' expectation horizons in addition to differences in elemental stressing are also responded to because of differences in knowledge about literature, knowledge of life and the experience of reading literature.

Keywords: responses, readers, expectations horizon
\end{abstract}

\begin{abstract}
Abstrak
Penelitian ini bertujuan untuk mendeskripsikan tanggapan pembaca terhadap novel Le Petit Prince, menguraikan horizon harapan pembaca terhadap novel Le Petit Prince, dan memaparkan faktor-faktor penyebab perbedaan tanggapan dan horizon harapan pembaca. Penelitian ini termasuk jenis penelitian deskriptif kualitatif. Ada dua sumber data yaitu sumber data primer dan sekunder. Sumber data primer mengacu pada objek penelitian yaitu novel Le Petit Prince, sedangkan data sekunder berupa teks-teks yang memuat tanggapan pembaca novel Le Petit Prince yang terdiri atas 20 orang, yang terdapat pada media massa cetak dan elektronik termasuk internet. Instrumen penelitian berupa tabel-tabel isian yang mengaitkan pembaca, tanggapan pembaca, dan horizon harapan. Data dikumpulkan dengan cara observasi dan data dianalisis dengan menggunakan teknik deskriptif kualitatif. Hasil penelitian yang didapat sebagai berikut. Pertama, seluruh pembaca menanggapi atau menilai positif unsur tema, alur, tokoh, latar, sudut pandang, gaya bahasa, teknik penceritaan, bahasa, dan isi novel Le Petit Prince. Kedua, harapan sebagian besar pembaca sebelum membaca novel Le Petit Prince sesuai dengan kenyataan ke sembilan unsur di dalam novel Le Petit Prince sehingga pembaca dapat dengan mudah menerima dan memberikan pujian pada novel tersebut. Ketiga, faktor penyebab perbedaan tanggapan dan horizon harapan pembaca
\end{abstract}


selain perbedaan stressing unsur yang ditanggapi juga karena perbedaan pengetahuan tentang sastra, pengetahuan tentang kehidupan dan pengalaman membaca karya sastra.

Kata-kata kunci: tanggapan, pembaca, horizon harapan

DOI: $10.26499 / j k . v 15 i 1.873$

How to cite: Intan, T. (2019). Le petit prince karya Antoine de Saint-Exupery dalam tanggapan dan horizon harapan pembaca. Kandai, 15(1), 87-100 (DOI: 10.26499/jk.v15i1.873)

\section{PENDAHULUAN}

Novel Le Petit Prince adalah sebuah karya berbahasa Perancis yang paling terkenal dari pengarang Antoine de Saint-Exupery, terbit pertama kali di New York pada tahun 1943. Novel ini merupakan salah satu dari karya utama atau chef d'oeuvre karena muatan nilai kemanusiaan yang sarat di dalamnya sehingga menjadi bacaan wajib bagi masyarakat Perancis. Penulisnya pun, seorang tentara dari angkatan udara, dianggap sebagai pahlawan nasional dan namanya tercatat di dinding monumen Panthéon.

Walaupun berkesan seperti buku anak-anak karena keberadaan tokoh Pangeran Cilik dan ilustrasi-ilustrasi di dalamnya, Le Petit Prince justru seringkali disebut sebagai buku filsafat karena menawarkan berbagai cara pandang dan ditanggapi secara beragam oleh para pembacanya. Buku ini telah diterjemahkan dalam lebih dari 300 bahasa, dan merupakan karya kedua di dunia yang paling banyak dialihbahasakan selain kitab-kitab suci. Le Petit Prince telah terjual lebih dari 12 juta eksemplar di Perancis dan difilmkan pada tahun 2015. Edisi Bahasa Indonesia buku tersebut diterbitkan pertama kali oleh Pustaka Jaya (1979), dan kemudian diterbitkan kembali dalam dua versi berbeda oleh Gramedia (2003 dan 2010) diterjemahkan oleh Henri Chambert-Loir dengan judul Pangeran Cilik.

Le Petit Prince yang awalnya berupa novel bertransformasi ke dalam berbagai wahana, seperti komik (dikaji oleh Rachmadiah, 2017), pertunjukan opera di Amerika Serikat dan Jerman, komedi musikal di Perancis dan Korea, pameran, integrasi dalam kurikulum Maroko, Kanada, dan Libanon. Di Jepang tepatnya di Hakone (di kaki gunung Fuji), ada sebuah museum yang didedikasikan untuk Le Petit Prince. Walaupun ditujukan seolah sebagai bacaan anak-anak, novel 'Pangeran Kecil' ini memiliki makna filosofis dan idealis tentang kehidupan manusia dan lingkungan sosial yang universal.

Antoine Marie-Roger de SaintExupéry (1900-1944) penulis Le Petit Prince, mendedikasikan karyanya tersebut bagi salah satu sahabatnya, Léon Werth, penulis dan kritikus seni, atau lebih tepatnya, Leon Werth pada masa kanak-kanak. Namun Antoine kemudian menyesal tidak mendedikasikannya untuk istrinya, Consuelo de Saint-Exupery, yang merupakan jiwa dari buku, yang diwakili oleh tokoh mawar yang angkuh dan rapuh pada saat yang sama. Setahun setelah penerbitan buku itu, Antoine menghilang dan dianggap meninggal dunia dalam misi Perang Dunia II pada tanggal 31 Juli 1944 di Afrika.

Pada tahun 2015, Paramount Animation menayangkan film berjudul The Little Prince sebagai hasil adaptasi novel tersebut. Perusahaan itu mengeluarkan dana hingga US \$77 juta dengan merekrut sutradara Max Oxborn yang sebelumnya membuat film animasi Kungfu Panda. Kesuksesan film The Little Prince terbukti dari diraihnya keuntungan sebesar US \$97 juta. Film yang berdurasi 108 menit ini tidak hanya 
sukses di Perancis tetapi juga di negaranegara lain seperti China, Jepang, dan Brazil.

Novel Le Petit Prince masih diapresiasi pembaca hingga saat ini melalui berbagai media terutama media cetak dan internet. Setelah sekitar delapan puluh tahun dari masa penciptaannya, novel ini masih dibaca, diresepsi, bahkan direka ulang, baik di Perancis maupun di negara-negara lainnya. Dalam konteks situasi ini, tanggapan pembaca dari masa yang sama maupun berbeda menjadi menarik untuk dikaji dengan pendekatan kajian resepsi sastra. Tanggapan pembaca biasanya menunjukkan banyak perbedaan di samping adanya persamaan. Adanya perbedaan itu disebabkan oleh horizon harapan yang berbeda-beda dan dipengaruhi oleh faktor-faktor yang berkaitan dengan latar belakang pembaca.

Fenomena bergesernya arah penelitian sastra dari teks pada pembaca ini ternyata telah menarik perhatian sejumlah peneliti. Beberapa kajian resepsi sastra telah dilakukan seperti di antaranya terhadap novel-novel Marcel Proust oleh Carrier-Lafleur (2011), novel Supernova karya Dee Lestari oleh Saraswati (2011), dan novel Pulang karya Leila S. Chudori oleh Yudistyanto (2013). Berdasarkan penelusuran yang telah dilakukan, kajian resepsi sastra terhadap novel Le Petit Prince yang menjadi objek material penelitian ini belum pernah dibuat, dan menjadi menarik untuk dilakukan.

Berdasarkan latar belakang tersebut dapat dirumuskan permasalahan penelitian sebagai berikut. Pertama, akan dibahas tanggapan serta horizon harapan pembaca terhadap novel Le Petit Prince Selanjutnya akan diuraikan faktor-faktor yang menyebabkan terjadinya perbedaan atau kesesuaian di antara tanggapan dan horizon harapan pembaca. Permasalahan-permasalahan tersebut dikaji dengan tinjauan resepsi sastra karena resepsi sastra memang merupakan pendekatan yang mengkhususkan perhatian terutama pada tanggapan pembaca.

\section{LANDASAN TEORI}

Ilmu sastra yang berhubungan dengan tanggapan pembaca terhadap karya sastra disebut estetika resepsi, yaitu ilmu yang didasarkan pada tanggapan pembaca atau resepsi pembaca terhadap karya sastra (Pradopo, 1986, hlm.182). Ilmu ini sering pula disebut rezeptionaesthetic yang diterjemahkan sebagai: (a) Literary response, (b) Penerimaan estetik (aesthetic of reception), atau (c) Resepsi sastra. Di Indonesia, ilmu ini diterjemahkan dan lebih dikenal dengan nama teori resepsi sastra, yaitu bagaimana pembaca memberikan makna terhadap karya sastra yang dibacanya, sehingga dapat memberikan reaksi/tanggapan terhadap karya sastra. Menurut teori resepsi sastra, suatu teks baru mempunyai makna bila teks itu sudah memiliki hubungan dengan pembaca. Teks memerlukan adanya kesan (wirkung) yang tidak mungkin ada tanpa pembaca. Resepsi sastra memberikan kebebasan kepada pembaca untuk memberikan makna kepada suatu teks sastra, meskipun kebebasan itu sebenarnya tidak pernah sempurna karena selalu ada unsur-unsur yang membatasinya (Junus, 1985, hlm.104).

Sebuah karya sastra menjadi konkret melalui penerimaan pembacanya sehingga meninggalkan kesan (wirkung) pada pembaca. Pembaca harus mengkonkretkan dan merekonstruksinya. Akan tetapi, hal ini tidak mungkin dilakukan tanpa imajinasi pembaca, karena tanpa imajinasi, pembaca tidak mungkin melihat karya sastra dalam suatu hubungan yang lebih luas. Imajinasi pembaca dimungkinkan oleh 
keakraban dengan tradisi sastra dan kesanggupan memahami keadaan pada masanya atau mungkin masa sebelumnya (Junus, 1985, hlm.51).

Melalui kesan, pembaca dapat menyatakan penerimaan terhadap suatu karya. Pembaca dapat menyatakannya dalam bentuk komentar, dan mungkin dalam bentuk karya yang lain yang berhubungan dengan karya sebelumnya dengan cara tertentu, yang mungkin bertentangan, parodi, demitefikasi, dan sebagainya. Karya sastra, lebih-lebih yang dianggap penting dari waktu ke waktu selalu mendapat tanggapan dari pembaca. Tanggapan pembaca itu umumnya berbeda satu sama lain. Hal ini selaras dengan pendapat Jauss (1974, hlm.14) yang menyatakan bahwa karya sastra selalu memberikan wajah yang berbeda kepada pembaca yang lain, selalu memberikan orkestrasi yang berbeda dari generasi yang satu ke generasi yang berikutnya.

Perbedaan tanggapan seorang pembaca dan pembaca lain dari suatu periode ke periode disebabkan oleh dua hal yang merupakan dasar teori estetika resepsi. Pertama, prinsip horizon harapan dan kedua prinsip tempat terbuka (Pradopo 1995, hlm.219). Horizon harapan adalah harapan-harapan pembaca karya sastra sebelum membaca karya sastra. Bila wujud harapan pembaca itu kemudian sesuai dengan wujud harapan dalam karya sastra yang dibacanya, ia akan dengan mudah menerimanya. Sebaliknya jika tidak sama wujud harapannya, ia akan bereaksi baik dengan sikap antusias maupun sikap menolaknya. Jika sebuah karya sastra akhirnya tidak ditanggapi oleh generasi berikutnya, karya itu hanya menjadi karya masa lalu yang tidak mempunyai nilai sejarah lagi.

Horizon harapan pembaca ditentukan oleh tiga kriteria (Segers, 1978, hlm.41). Pertama, oleh normanorma yang terpancar dari teks-teks yang telah dibaca. Kedua, ditentukan oleh pengetahuan dan pengalaman atas semua teks yang telah dibaca sebelumnya. Ketiga, ditentukan oleh pertentangan antara fiksi dan kenyataan, yaitu kemampuan pembaca untuk memahami karya sastra baik dalam horizon sempit dari harapan-harapan sastra maupun horizon luas dari pengetahuannya tentang kehidupan. Di samping horizon harapan, perbedaan tanggapan pembaca juga disebabkan oleh tempat terbuka dalam karya sastra. Hal ini berhubungan dengan sifat karya sastra yang polyinterpretable.

Dalam resepsi sastra, tanggapan pembaca terhadap karya sastra diteliti. Adapun pembaca yang dimaksud adalah pembaca aktif, yaitu pembaca yang menanggapi karya sastra dengan sudut pandang tertentu secara tertulis. Mereka ini memberikan komentar-komentar dan penilaian berdasarkan konkretisasi terhadap karya sastra yang dibacanya (Vodicka, 1964, hlm.78). Dengan demikian, penelitian dengan metode resepsi sastra adalah merekonstruksi bermacam konkretisasi karya sastra dalam masa sejarahnya dan meneliti hubungan di antara konkretisasikonkretisasi itu di satu pihak, dan di lain pihak meneliti hubungan antara karya sastra dengan konteks historis yang mewakili konkretisasi-konkretisasi tersebut.

Dalam penelitian resepsi terdapat dua bentuk kajian yaitu (1) resepsi secara sinkronis dan (2) resepsi secara diakronis. Bentuk pertama meneliti karya sastra dalam hubungannya dengan pembaca sezaman. Bentuk kedua dianggap lebih rumit karena melibatkan pembaca sepanjang sejarah (Ratna, 2011, hlm.167). Penelitian ini menggunakan bentuk resepsi sastra yang pertama, yaitu resepsi sastra secara sinkronis, karena tanggapan pembaca yang diteliti adalah tanggapan pembaca sezaman, yaitu pembaca yang 
menanggapi novel Le Petit Prince dalam periode tahun 2013 sampai dengan tahun 2018.

\section{METODE PENELITIAN}

\begin{abstract}
Penelitian ini termasuk jenis deskriptif kualitatif yang menggambarkan dan menginterpretasi objek apa adanya. Penelitian semacam ini membutuhkan kekuatan analisis yang mendalam dan terperinci namun meluas dan holistik. Dengan demikian, kekuatan akal menjadi satu-satunya sumber kemampuan analisis dalam seluruh proses penelitian (Arikunto, 2010, hlm.5).
\end{abstract}

Menurut Teeuw (1984, hlm.160167), ada tiga metode penelitian resepsi sastra, yaitu (1) penelitian resepsi sastra secara eksperimental, (2) penelitian resepsi lewat kritik sastra dan penciptaan karya sastra "baru", serta (3) penelitian resepsi intertekstual. Penelitian (1) dilakukan untuk resepsi masa kini. Penelitian (2) dapat dilakukan dengan dua cara, yaitu secara sinkronik atau diakronik. Penelitian resepsi secara sinkronik berarti meneliti resepsi sastra dalam satu kurun waktu atau satu periode saja, sedangkan penelitian resepsi sastra secara diakronik berarti meneliti resepsi sastra sepanjang sejarahnya dari periode ke periode. Penelitian (3) dapat dilakukan dengan cara membandingkan karya-karya yang memiliki kaitan intertekstual.

Metode yang digunakan dalam penelitian ini adalah penelitian kedua yaitu metode resepsi sastra secara sinkronik. Sumber data penelitian ini adalah data primer berupa novel Le Petit Prince, dan data sekunder berupa tanggapan pembaca dari berbagai media daring. Pengumpulan data dilakukan dengan metode studi pustaka yang ditopang dengan teknik baca, catat, simak, dan transkripsi.

\section{PEMBAHASAN}

Berikut ini akan diuraikan ringkasan cerita dari novel Le Petit Prince yang menjadi objek penelitian agar didapatkan pemahaman menyeluruh tentang narasi cerita. Selanjutnya akan dibahas tanggapan para pembaca terhadap novel tersebut.

\section{Sinopsis Novel Le Petit Prince}

Narator adalah seorang pilot Perancis, yang karena pesawatnya mengalami kerusakan, ia harus mendarat di gurun Sahara dan memperbaiki sendiri mesin pesawatnya. Keesokan paginya, ia terbangun karena suara seorang anak berambut kuning keemasan yang memintanya menggambar seekor domba. Karena terkejut oleh permintaan tersebut, sang pilot mengikuti keinginan anak itu, namun domba-domba yang digambarnya tidak sesuai dengan keinginan anak tersebut. Akhirnya pilot menggambar sebuah kandang dan menunjukkan bahwa domba yang diinginkan ada di dalamnya. Anak itu, seorang pangeran kecil, akhirnya merasa puas dan menyatakan bahwa dombanya sedang tidur.

Setelah pertemuan itu, mereka terus bersama. $\mathrm{Si}$ pangeran kecil menerangkan asal usulnya, yaitu dari suatu planet yang disebut oleh orang dewasa sebagai Asteroid B 612, yang luasnya sedikit lebih besar dari sebuah rumah. Kegiatan pangeran kecil itu terutama adalah menyapu gununggunung berapi setinggi lutut dan mencabuti pohon-pohon baobab yang bisa merusak planetnya. Setelah itu, ia akan menatap matahari terbenam. Planetnya begitu kecil sehingga ia hanya cukup menggeser kursinya sedikit saja. Pada suatu ketika, ia menyaksikan matahari tenggelam sebanyak 44 kali, ia menyatakan pada sang pilot bahwa ketika bersedih, orang akan menyukai 
pemandangan semacam itu. Ia pun melakukan perjalanan dan menemukan banyak jenis orang yang menjadi dewasa dalam kesendirian mereka.

Setelah deretan kilas balik itu, sang pilot kembali menceritakan kondisinya. Saat mulai sekarat karena kehausan, sang pilot dan pangeran kecil berjalan melintasi gurun dan akhirnya menemukan sebuah sumur. Sang pangeran kecil mengingatkan bahwa gurun itu tampak cantik, karena ia menyembunyikan mata air di dalamnya. Hal-hal yang tersembunyi itulah yang membuat segalanya memiliki arti.

Keesokan harinya, sang pilot melihat sang pangeran kecil kembali berbicara ke si ular. Ia menjadi sangat resah. Apalagi kemudian sang pangeran kecil mengucapkan selamat tinggal karena sudah waktunya ia kembali ke planet asalnya. Ia seperti akan mati karena tidak mungkin membawa tubuhnya kembali ke planet yang jauh itu. Sang pilot berusaha mencegah, namun berjalan di gurun membuat dirinya lelah. Ia tak berdaya melihat sang pangeran kecil dipatuk ular kuning dan terjatuh tanpa suara. Tak lama, sang pilot pun diselamatkan dan kembali ke negerinya. Para penyelamatnya tidak menemukan tubuh si pangeran kecil yang dianggapnya ditelan bumi. Cerita berakhir dengan gambar pemandangan tempat sang pangeran kecil datang ke bumi dan ketika sang ular mengambil nyawanya. Sang pilot meminta kepada pembaca jika menemukan seseorang anak kecil aneh yang menolak untuk menjawab pertanyaan, untuk menghubunginya secepat mungkin. Sang pangeran kecil dikisahkan sudah berada selama satu tahun di Bumi, dan sang narator mengakhiri ceritanya 6 tahun setelah ia diselamatkan dari gurun itu.

\section{Tanggapan Pembaca terhadap Novel Le Petit Prince}

Dalam bagian ini, tanggapan, komentar, penilaian dan sikap pembaca terhadap novel Le Petit Prince telah diolah dan disunting sesuai keperluan penelitian. Hanya tanggapan yang relevan dan yang dibutuhkan untuk menjawab masalah saja yang disampaikan dalam penelitian ini.

Penanggap novel Le Petit Prince berjumlah 20 orang yang tidak diketahui baik latar belakang maupun identitasnya, dan menyampaikan resepsinya dalam berbagai laman internet. Komentar atau review dinyatakan dalam bahasa Perancis (12 orang, $60 \%$ dari keseluruhan responden), bahasa Indonesia (6 orang, 30\%), dan bahasa Inggris (2 orang, 10\%). Tidak semua penanggap mengomentari setiap aspek pembentuk novel Le Petit Prince. Sebagian besar penanggap menyoroti aspek-aspek tertentu yang menjadi perhatian atau yang dianggap sangat menarik, unik, dan unggul atau sebaliknya yang dianggap sebagai sisi lemah novel Le Petit Prince. Hal ini menjadi konsekuensi dari cara pengumpulan data yang tidak menggunakan seperangkat pertanyaan kuesioner. Data yang dikumpulkan berupa tulisan yang berisi tanggapan bebas (tidak diarahkan) dari pembaca terhadap novel Le Petit Prince yang dikutip dari berbagai laman dan blog. Tabel-tabel yang ditampilkan berikut ini merupakan hasil apropriasi dan modifikasi dari penelitian Dermawan dan Ajisaputra (2014).

Tanggapan pembaca novel Le Petit Prince berupa tanggapan positif $(+)$ dan tanggapan negatif (-). Tanggapan positif dapat berupa pujian, penunjukan kelebihan, keunggulan, keunikan dan kehebatan, sedangkan tanggapan negatif dapat berupa penunjukan kelemahan atau kekurangan novel Le Petit Prince. 
Tabel 1

Tanggapan Pembaca Novel Le Petit Prince

\begin{tabular}{c|l|l|l|l|c|c|c|c|c|c|c}
\hline \multirow{2}{*}{ No } & \multirow{2}{*}{ Nama Penanggap } & \multirow{2}{*}{ Bahasa } & \multicolumn{7}{|c|}{ Tanggapan } & \multicolumn{2}{c}{$\begin{array}{c}\text { Isi } \\
\text { cerita }\end{array}$} \\
\hline & & & $\mathbf{1}$ & $\mathbf{2}$ & $\mathbf{3}$ & $\mathbf{4}$ & $\mathbf{5}$ & $\mathbf{6}$ & $\mathbf{7}$ & $\mathbf{8}$ & + \\
\hline 1 & Jorge L & Inggris & + & & & & & - & & & + \\
\hline 2 & Sandra & Inggris & + & & + & & & & & & + \\
\hline 3 & Nancy & Indonesia & + & + & + & + & + & & + & + & + \\
\hline 4 & Bakanekonomama & Indonesia & + & + & + & + & & + & + & & + \\
\hline 5 & Dion Yulianto & Indonesia & + & + & + & + & & & + & + & + \\
\hline 6 & Bima Satria & Indonesia & + & + & + & + & + & + & & & + \\
\hline 7 & NabilaSant & Indonesia & + & & + & + & & + & + & & - \\
\hline 8 & Spicameter & Indonesia & + & & + & & & & + & & + \\
\hline 9 & Nastasia B & Perancis & + & & & & & + & + & + & + \\
\hline 10 & Piatka & Perancis & + & + & + & + & + & & + & & + \\
\hline 11 & Respirer & Perancis & + & & & & & & & & + \\
\hline 12 & Isajulia & Perancis & + & & & & & & & + & + \\
\hline 13 & Philippe 67 & Perancis & & & & + & & & & & + \\
\hline 14 & Stelphique & Perancis & + & & + & & & + & & & + \\
\hline 15 & Jmlyr & Perancis & + & & + & + & & & & & + \\
\hline 16 & Jujuramp & Perancis & & + & + & + & + & & + & & + \\
\hline 17 & Blurb & Perancis & + & + & & & & & & & + \\
\hline 18 & Laurence & Perancis & + & & + & + & & + & + & & + \\
\hline 19 & Kyslegion & Perancis & + & + & + & + & & & & & + \\
\hline 20 & Katsu & Perancis & + & + & + & + & + & & & & + \\
\hline
\end{tabular}

1. Keterangan
1. Tema
2. Alur
3. Tokoh
4. Latar
5. Sudut Pandang
6. Gaya Bahasa
7. Teknik Penceritaan
8. Bahasa

2. Tanda

$$
\begin{array}{ll}
+\quad & \text { : tanggapan positif } \\
-\quad & \text { : tanggapan negatif } \\
& \text { : tidak ada tanggapan }
\end{array}
$$

Tabel 1 tersebut dapat dibaca sebagai berikut. Novel Le Petit Prince yang ditanggapi terdiri dari 9 unsur, yaitu tema, alur, tokoh, latar, sudut pandang, gaya bahasa, teknik penceritaan, bahasa, dan ekstrinsik (isi). Dari 20 orang, tidak ada penanggap yang memberi tanggapan secara lengkap pada semua unsur. Unsur yang mendapat tanggapan dari seluruh responden $(100 \%)$ adalah unsur ekstrinsik (isi). Hal ini dapat dipandang wajar karena sebagian besar atau umumnya pembaca karya sastra dimotivasi oleh keinginan untuk mengetahui isi dari karya sastra.Isi itu pula yang sering pertama kali ditanyakan oleh orang yang belum membaca suatu karya sastra kepada orang yang telah membacanya. Sebaliknya, unsur yang paling sedikit mendapat tanggapan dari pembaca/ penanggap adalah unsur bahasa.Unsur ini hanya ditanggapi oleh 4 pembaca atau penanggap atau hanya ditanggapi oleh $20 \%$ pembaca/penanggap. Kondisi ini dapat dipahami atau dimaknai karena kecilnya atensi pembaca/penanggap terhadap unsur bahasa, yang disebabkan oleh terpusatnya konsentrasi penanggap dalam menginterpretasi isi dan bukan bahasa sebagai unsur pembentuk novel. Selain itu, dapat pula diartikan bila penggunaan bahasa oleh pengarang (dan hasil terjemahan) dianggap telah sangat memadai sehingga tidak ditemukan kesalahan atau kejanggalan.

Dari tabel tersebut juga dapat dilihat fenomena tingginya tanggapan positif berjumlah 97 yang tersebar pada setiap unsur yang ditanggapi, dibandingkan dengan tanggapan negatif yang hanya diajukan oleh 2 orang. Satu penanggap menganggap gaya bahasa yang digunakan pengarang tidak tepat/ 
akan terlalu sulit dipahami bila publiknya adalah anak-anak, dan satu penanggap lain menganggap kekurangan novel Le Petit Prince secara ekstrinsik adalah jumlah halaman yang minimal (hanya 112 halaman) sehingga buku itu dinilai terlalu tipis.

Adapun perhitungan tanggapan yang diberikan para pembaca dapat dilihat pada tabel di bawah ini, yang menunjukkan jumlah penanggap, unsur yang tidak ditanggapi serta persentasenya.

Tabel 2

Unsur Cerita dan Jumlah Penanggap

\begin{tabular}{c|l|c|c|c|c}
\multicolumn{2}{c}{ Unsur Cerita dan Jumlah Penanggap } \\
\hline No & Unsur & $\begin{array}{c}\text { Jumlah } \\
\text { penang- } \\
\text { gap }\end{array}$ & $\begin{array}{c}\text { Yang } \\
\text { tidak } \\
\text { ditang- } \\
\text { gapi }\end{array}$ & $\%$ \\
\hline 1 & Tema & 18 & 90 & 2 & 10 \\
\hline 2 & Alur & 9 & 45 & 11 & 55 \\
\hline 3 & Tokoh & 14 & 70 & 6 & 30 \\
\hline 4 & Latar & 12 & 60 & 8 & 40 \\
\hline 5 & $\begin{array}{l}\text { Sudut } \\
\text { pandang }\end{array}$ & 5 & 25 & 15 & 75 \\
\hline 6 & $\begin{array}{l}\text { Gaya } \\
\text { bahasa }\end{array}$ & 7 & 35 & 13 & 65 \\
\hline 7 & $\begin{array}{l}\text { Teknik } \\
\text { penceritaan }\end{array}$ & 9 & 45 & 11 & 55 \\
\hline 8 & Bahasa & 4 & 20 & 16 & 80 \\
\hline 9 & Isi cerita & 19 & 95 & 1 & 5 \\
\hline
\end{tabular}

Dari tabel 2 tersebut, diketahui bahwa unsur yang paling banyak ditanggapi adalah isi cerita $(95 \%)$ dan tema $(90 \%)$, selanjutnya tokoh $(70 \%)$ dan latar (60\%). Hal ini dapat dipahami bahwa keempat unsur tersebut (isi cerita, tema, tokoh, dan latar) merupakan kekuatan dari novel Le Petit Prince yang dinilai sangat menonjol, sehingga unsurunsur lain yang bersifat teknis tidak terlalu mendapat perhatian. Alur dan teknik penceritaan masing-masing ditanggapi oleh $45 \%$ pembaca, gaya bahasa ditanggapi $35 \%$, dan sudut pandang serta bahasa masing-masing hanya ditanggapi $25 \%$ dan $20 \%$ pembaca saja.

Berikut ini diuraikan jumlah penanggap, penanggap positif, penanggap negatif beserta persentase masing-masing.

Tabel 3

Unsur Cerita dan Persentase Penanggap (+) dan (-)

\begin{tabular}{|c|c|c|c|c|c|c|}
\hline No & Unsur & $\begin{array}{c}\text { Jml } \\
\text { penang- } \\
\text { gap }\end{array}$ & $\begin{array}{c}\text { Penan } \\
\text { ggap } \\
(+)\end{array}$ & $\%$ & $\begin{array}{c}\text { Penan } \\
\text { ggap } \\
(-)\end{array}$ & $\%$ \\
\hline 1 & Tema & 18 & 18 & 100 & 0 & 0 \\
\hline 2 & Alur & 9 & 9 & 100 & 0 & 0 \\
\hline 3 & Tokoh & 14 & 14 & 100 & 0 & 0 \\
\hline 4 & Latar & 12 & 12 & 100 & 0 & 0 \\
\hline 5 & $\begin{array}{l}\text { Sudut } \\
\text { pandang }\end{array}$ & 5 & 5 & 100 & 0 & 0 \\
\hline 6 & $\begin{array}{l}\text { Gaya } \\
\text { bahasa }\end{array}$ & 7 & 6 & 85,7 & 1 & $\begin{array}{c}14, \\
3\end{array}$ \\
\hline 7 & $\begin{array}{l}\text { Teknik } \\
\text { pencerita } \\
\text { an }\end{array}$ & 9 & 9 & 100 & 0 & 0 \\
\hline 8 & Bahasa & 4 & 4 & 100 & 0 & 0 \\
\hline 9 & Isi cerita & 19 & 18 & 94,8 & 1 & 5,2 \\
\hline
\end{tabular}

Tabel 3 tersebut menunjukkan dari 99 tanggapan yang diberikan para pembaca terhadap unsur-unsur novel $L e$ Petit Prince, 97 tanggapan bersifat positif (98\%) dan 2 tanggapan bersifat negatif $(92 \%)$. Hasil ini memperlihatkan bahwa seluruh pembaca memberikan tanggapan atau penilaian cenderung sangat positif pada novel tersebut, terutama pada unsur tema, alur, tokoh, latar, sudut pandang, teknik penceritaan, dan bahasa, yang seluruhnya mendapat $100 \%$ tanggapan positif. Tanggapan negatif sangat kecil jumlahnya datang dari $5,2 \%$ pembaca untuk isi cerita dan $14,3 \%$ pembaca untuk gaya bahasa, namun tetap kedua unsur tersebut mendapatkan tanggapan positif di atas $85 \%$. Dengan paparan mengenai tanggapan ini, dapat disimpulkan bahwa novel Le Petit Prince ditanggapi positif oleh para pembaca karena dianggap memiliki keunggulan dan kekuatan pada setiap unsurnya.

Uraian mengenai apresiasi positif dan negatif dari tabel tersebut dibahas secara lebih jelas pada bagian horizon harapan pembaca berikut ini. 


\section{Horizon Harapan Pembaca Novel Le Petit Prince}

Pada subbagian sebelumnya, telah disebutkan bahwa tanggapan pembaca terhadap novel Le Petit Prince dapat berbeda-beda satu sama lain. Tanggapan-tanggapan itu dapat digolongkan menjadi dua tipe, yaitu tanggapan positif dan tanggapan negatif. Perbedaan tanggapan dapat disebabkan oleh perbedaan horizon harapan pembaca (harapan-harapan pembaca sebelum membaca novel Le Petit Prince), dan adanya ruang terbuka dari teks novel tersebut sehingga menimbulkan keragaman interpretasi para pembaca atau penanggapnya.

Menurut para responden, ada beberapa hal yang menjadi daya tarik awal bagi mereka sebelum membaca novel Le Petit Prince, di antaranya yaitu: tampilan sampul depan dan ilustrasi yang menarik (5 orang, 25\%). Empat pembaca (20\%) menyatakan ketertarikan mereka pada novel ini karena mengetahui ada versi film berbahasa Inggris. Selain itu, Le Petit Prince telah dikenal umum sebagai bacaan filsafat ringan sehingga 7 orang (35\%) merasa ingin membacanya. Arti penting novel tersebut ditunjukkan misalnya oleh seorang pembaca yang pada akhirnya mendapatkan buku ini setelah sebelumnya cukup lama mencari. Seorang pembaca bernama Satria (2016) yang menyatakan membeli novel Pangeran Kecil sebagai penanda simbolis dari gaji pertamanya.

Sebagian besar pembaca novel Le Petit Prince pada awalnya mengira bahwa buku tersebut murni ditujukan pada pembaca anak-anak, mengingat di dalamnya banyak dihiasi dengan gambar dan ilustrasi sederhana yang terbuat dari cat air, seperti dinyatakan Nancy dalam Vox (2015) "lukisan cat air yang simpel namun sangat berkesan" dan tokoh utamanya bernama Pangeran Kecil.
Namun demikian, setelah membaca novel tersebut dengan lebih fokus, para pembaca kemudian menyadari bahwa buku itu memuat hal-hal yang penting dan mendalam.

Jorge dalam Vox (2015) misalnya, menyatakan dirinya menjadi tidak yakin bahwa Le Petit Prince adalah novel untuk anak, "I'd say that teenagers and adults would enjoy this book the most" "Menurutku para remaja dan orang dewasa yang paling bisa menikmatinya". Kesan kekanakan menurut Nastasia (2013) berasal dari "Une tonalité enfantine [qui] se dégage de l'emploi d'un lexique minimaliste, qui donne l'illusion d'un répertoire pour enfant [...]" "Nada kekanakan [yang] muncul dari penggunaan kosakata minimalis yang memberikan bayangan mengenai kata-kata untuk anak-anak [...]".

Keraguan bahwa novel Le Petit Prince adalah buku untuk anak-anak juga misalnya terungkap pada tanggapan Nastasia (2013), yaitu karena di dalamnya "beaucoup plus porteuse d'un message philosophique à l'adresse des adultes" "banyak memuat pesan filosofis yang ditujukan pada orang dewasa". Hal sama dinyatakan Jlmyr (2017) yang menyatakan "Un conte philosophique" "sebuah cerita filosofis", "ce livre était si beau, si poétique, si riche de messages philosophiques" "buku ini begitu indah, begitu puitis, begitu kaya dengan pesan filosofis."

Tema novel ini menurut Spicameter dalam Vox (2015) berbicara tentang 'sebuah kisah yang menceritakan tentang makna kesendirian, persahabatan, cinta, dan kehilangan'. Tanggapan mengenai alur diuraikan Nastasia (2013) sebagai berikut, "Cette narration est segmentée en 27 chapitres de longueurs inégales, qui ont chacun une grande cohérence interne mais qui n'ont pas forcément un grand rapport avec le chapitre directement précédent 
ou suivant." "Narasi ini terdiri dari 27 bab dengan panjang berbeda yang masing-masingnya memiliki koherensi internal yang besar tapi tidak selalu memiliki hubungan erat dengan bab sebelum atau sesudahnya."

Pangeran Kecil sebagai tokoh utama novel Le Petit Prince digambarkan Bakanekonomama (2011) sebagai sosok yang membuatnya jatuh cinta, 'dia begitu polos, baik hati, tidak sombong, cinta tanah air, dan peduli pada sesama'. Begitu murninya karakter tokoh tersebut, hingga Stelphique menanggapi sebagai berikut, "Je me sens si proche de sa candeur, de sa perplexité face aux adultes et leur comportements bizarre", "Saya merasa begitu dekat dengan kepolosannya, keraguannya berhadapan dengan orang-orang dewasa dan kelakuan mereka yang aneh."

Adapun mengenai tokoh-tokoh lain dalam novel tersebut dibahas oleh Kyslegion (2015) dengan sangat teliti. Mereka merepresentasikan tatanan masyarakat dan individu-individu yang ada di dalamnya, yang diwakili oleh planet-planet yang dikunjungi Pangeran Kecil sebagai latar tempatnya, mulai dari seorang raja yang menunjukkan dominasi dan otoritas, seorang laki-laki angkuh yang selalu ingin dikagumi, seorang pemabuk malang yang minum untuk melupakan rasa malunya karena ia minum, seorang pengusaha yang sangat tamak dan perhitungan, petugas yang menyalakan lampu saat sore hari yang selalu patuh dan rajin, ahli geografi yang serbatahu dan menjadi penakut. Semua tokoh ini menunjukkan karakter yang tidak bahagia, tidak bisa mencintai dan dicintai.

Sudut pandang, gaya bahasa, teknik penceritaan, dan aspek bahasa yang digunakan pengarang secara keseluruhan juga ditanggapi secara sangat baik oleh para pembaca. Bakanekonomama menyatakan pujiannya, "Saya sangat suka dengan gaya Saint-Exupéry menyisipkan sindiran-sindiran mengenai sikap orang dewasa yang menganggap diri mereka bijaksana, terhormat, dan pandai padahal sebenarnya tidak". Menurut Dion (2012), "Dengan bahasa yang lugas namun mendalam, si Pangeran Kecil telah menyadarkan kembali si Penerbang dalam merenungkan kembali keberadaannya di dunia sebagai orang dewasa."

Isi cerita ditanggapi secara positif oleh seluruh pembaca, mulai dari 'isinya mendalam dan bahkan idealis' (Nancy), 'mengajarkan banyak kebijaksanaan dan kedewasaan' (Bakanekonomama), dan 'memuat pelajaran yang amat berharga' (Dion). Satria (2016) menegaskan bahwa novel ini 'mengandung pelajaran yang amat berharga' dan merekomendasikannya bagi mereka yang ingin belajar lebih tentang arti hidup dan lupa pernah menjadi anakanak.

Seluruh responden yang memberi tanggapan dalam bahasa Perancis menyatakan telah membaca novel ini lebih dari satu kali, mulai dari masa kanak-kanak, pada masa remaja, dan pada masa dewasa, dengan pemahaman yang berbeda sesuai perkembangan wawasan. Beberapa pembaca juga menyatakan kesediaannya membaca ulang novel tersebut karena meyakini akan adanya sudut pandang baru seperti diujarkan Katsu (2015) berikut ini, "Une relecture future me semble intéressante" "Pembacaan ulang di masa depan tampaknya menarik bagi saya", dan "Une ouvre à découvrir, redécouvrir encore et encore" "Sebuah karya untuk digali, digali kembali, lagi dan lagi."

Harapan sebagian besar pembaca sebelum membaca novel Le Petit Prince sesuai atau terpenuhi dengan kenyataan atau fakta dalam karya sastra saat pembaca membaca novel tersebut. Kenyataan yang dimaksud berupa tema, 
alur, tokoh, latar, sudut pandang, gaya bahasa, teknik penceritaan, bahasa, dan isi cerita dalam novel tersebut. Oleh karena itu, sebagian besar pembaca dengan mudah menerima novel Le Petit Prince dengan penilaian positif, pujian, dan kekaguman, seperti yang dinyatakan Isajulia "Ce livre est très addictif" "Buku ini sangat membuat ketagihan", "Un livre incontournable! [...] Pour moi c'est une oeuvre de philosophie majeure "Sebuah buku yang luar biasa! [...]" (Philippe). "Untuk saya, ini adalah sebuah karya filsafat yang penting", dan "Un trésor de la littérature française" "Sebuah harta karun dari kesusastraan Perancis" (Stelphique).

\section{Faktor-faktor Penyebab Perbedaan atau Kesesuaian antara Tanggapan dan Horizon Harapan Pembaca}

Kesenjangan di antara horizon harapan pembaca dan tanggapan setelah membaca dapat terjadi karena beberapa faktor. Pertama, perbedaan tanggapan pada novel Le Petit Prince terjadi karena perbedaan penekanan pada unsur yang ditanggapi. Ada pembaca yang hanya menanggapi 1 unsur saja (dalam hal ini latar), ada yang 2 unsur, 3 unsur dan seterusnya. Perbedaan ini juga disebabkan oleh kesenjangan kemampuan pembaca dalam merespon novel tersebut, yang dipengaruhi oleh perbedaan pengetahuan tentang sastra, tentang kehidupan, dan pengalaman membaca karya sastra. Kedua, dari data yang terkumpul, faktor identitas, pendidikan, atau latar belakang keluarga pembaca, tidak dapat dijadikan alasan perbedaan tanggapan atau horizon harapan karena tanggapan mereka mengenai novel Le Petit Prince diperoleh melalui laman dan blog pada internet. Informasi personal mengenai para pembaca ini tidak dicantumkan.

Berdasarkan hasil penelitian

diketahui bahwa antara tanggapan dengan horizon harapan pembaca terdapat kesesuaian karena para pembaca sebagai pemberi tanggapan secara keseluruhan dapat menerima, memberi nilai positif, dan juga pujian terhadap novel Le Petit Prince. Dengan demikian para pembaca dapat disebut sebagai penikmat karya sastra yang aktif, hal ini ditunjukkan oleh apresiasi dan partisipasi mereka dalam bentuk tulisan di laman dan blog bacaan internet.

\section{PENUTUP}

Hasil penelitian dan pembahasan menunjukkan bahwa tanggapan pembaca terhadap novel Le Petit Prince yang meliputi unsur tema, alur, tokoh, latar, sudut pandang, teknik penceritaan, dan bahasa dinilai/ditanggapi sangat positif oleh $100 \%$ pembaca/penanggap unsurunsur tersebut, sedangkan unsur gaya bahasa dan isi cerita ditanggapi positif oleh sekitar $85 \%$ pembaca/penanggap. Dengan demikian, novel Le Petit Prince dipandang memiliki keunggulan dan kekuatan pada semua unsur yang membangunnya.

Harapan sebagian besar pembaca novel Le Petit Prince sebelum membaca novel tersebut ternyata sesuai dengan kenyataan atau fakta karya tersebut, sehingga sebagian besar pembaca dapat dengan mudah menerima novel itu dengan berbagai penilaian positif, pujian, dan pernyataan kekaguman. Faktor-faktor penyebab perbedaan atau kesesuaian di antara tanggapan dan horizon harapan pembaca selain karena adanya stressing unsur yang ditanggapi juga bisa terjadi karena pengetahuan tentang sastra, tentang kehidupan, dan pengalaman membaca karya sastra.

\section{DAFTAR PUSTAKA}

Arikunto, S. (2010). Prosedur Penelitian Suatu Pendekatan Praktik. Jakarta: Rineka Cipta. 
Bakanekonomama. (2011). Review The Little Prince. https://www.goodreads.com/revi ew/show/243528273. diakses tanggal 12 September 2018.

Carrier-Lafleur, T. (2011). Le rôle des déceptions dans $A$ la recherche $d u$ temps perdu de Marcel Proust. Autofiction, crise du sujet et montage identitaire. Etudes Litteraires 42(2).

Dermawan, R. \& Ajisaputra, C. (2014). Tanggapan Pembaca Terhadap Novel Ayat-Ayat Cinta Karya Habiburrahman El Shirazy: Tinjauan Resepsi Sastra. CARAKA.1(1). Desember 2014.

Dion. (2012). The Little Prince (Pangeran Kecil) https://dionyulianto.blogspot.com /2012/10/the-little-princepangeran-kecil.html. diakses tanggal 13 September 2018.

Jauss, H. R. (1974). Literary History As A Chalenge dalam Ralp Caken (Ed). London: New Direction in Literary History Rudledje \& Kegan Paul.

Junus, U. (1985). Resepsi Sastra, Sebuah Pengantar. Jakarta: Gramedia.

Katsu. (2015). Critique Le Petit Prince Antoine de SaintExupery.https://lespetiteslectures depauline.wordpress.com/2015/0 7/24/critique-le-petit-princeantoine-de-saint-exupery/ diakses tanggal 13 September 2019.
Kyslegion, A. (2015). Avis sur Le Petit Prince.https://www.senscritique. com/livre/Le_Petit_Prince/critiqu e/46850811. diakses tanggal 14 September 2018.

Nastasia. (2013). Critiques de le Petit Prince.https://www.babelio.com/ livres/Saint-Exupery-Le-PetitPrince/36712/critiques. Diakses 12 September 2018.

Pradopo, R. D. (1986). "Estetika Resepsi, Teori dan Penerapannya" dalam Sulastin Sutrisno dkk. Bahasa dan Budaya. Yogyakarta: Gadjah Mada University Press.

Pradopo, R. D. (1995). Beberapa Teori Sastra, Metode Kritik, dan Penerapannya. Yogyakarta: Pustaka Pelajar.

Rachmadiah, T. P. (2017). Analisis Struktural Intrinsik Dalam Transformasi Novel Le Petit Prince Ke Komik The Little Prince. Skripsi. Malang: Universitas Brawijaya.

Ratna, N. K. (2011). Teori, Metode, dan Teknik Penelitian Sastra. Yogyakarta: Pustaka Pelajar.

Saint-Exupéry, A. de. (1999). Le Petit Prince. Paris: Gallimard.

Saint-Exupéry, A. de. (2009). Pangeran Kecil. Jakarta: PT Gramedia Pustaka Utama.

Saraswati, E. (2011). Resepsi Estetis Pembaca Terhadap Novel Supernova Karya Dee Lestari. Atavisme. 14 (2). 156-169. 
Satria, B. (2016). Book's Review Le Petit Prince (The Little Prince).http://milkywaybs.blogspot.com/2016/12/booksreview-le-petit-prince-little.html. diakses tanggal 14 September 2018.

Segers, R. T. (1978). The Evaluation of Literary Texts. Lisse: The Peter de Ridder Press.

Teeuw, A. 1984. Sastra dan Ilmu Sastra: Pengantar Teori Sastra. Jakarta: Pustaka Jaya.

Vodicka, F. (1964). "The History of The Echo of Literary Words" dalam Paul L. Garvin (Ed). A Prague School Reader on Esthetics, Literary Structure and Style.Washington

Vox. (2015). Derrière Le Petit Prince Une Leçon de Philosophie. $\mathrm{http}: / / \mathrm{www}$. lefigaro.fr/vox/cultur e/2015/07/29/3100620150729ARTFIG00277derriere-le-petit-prince-unelecon-de-philosophie.php. diakses tanggal 15 September 2018.

Yudistyanto, U. M. (2013). Pendekatan Sosiologi Sastra, Resepsi Sastra, dan Nilai Pendidikan dalam Novel Pulang Karya Leila S. Chudori. Tesis. Surakarta: UNS. 
Kandai Vol. 15, No. 1, Mei 2019; 87-100 